\title{
Reflections on the Mediostructure in Special-Field Dictionaries. Also According to the Example of the Dictionary for Lexicography and Dictionary Research*
}

Herbert Ernst Wiegand, Germanistisches Seminar, University of Heidelberg, Heidelberg, Germany (herbert.ernst.wiegand@gs.uni-heidelberg.de)

One who runs alone cannot be outrun by another

(Ethiopian proverb)

\begin{abstract}
The central question posed in this contribution is: What constitutes the difference between a special-field dictionary article giving a cross-reference with a fixed textual reference position on the one hand, and a special-field dictionary article giving a cross-reference without a fixed reference position on the other, with regard to systematic cross-referencing? Because this very special type of question can only be answered systematically with reference to a theory of the mediostructure, some necessary terms are firstly introduced by means of illustrative analyses of special-field dictionary articles giving cross-references, such as e.g. homogeneously externally orientated dictionary article, heterogeneously externally orientated dictionary article, item identifying the starting-point of the reference, item giving the reference, item giving a reference marker, mediostructural article network, the user's pre-knowledge relevant to the reference, position-bound reference, item-bound reference, single and expanded domain for the starting-point for the reference, mediostructural selection and many more. On the basis of various analyses of different special-field dictionary articles with variable and fixed reference positions, a picture evolves which comes close to the situation where the question at the beginning of the contribution can be answered as follows: When the results of an appropriate mediostructural selection are presented by means of the application of the method of itembound reference in special-field dictionaries with a variable reference position, and also when this happens by means of the application of the method of position-bound reference in special-field dictionaries with a fixed reference position, it is possible in principle that a systematic reference orientated to the dictionary functions can result. It can continuously be established, however, that in special-field dictionary articles with a fixed reference position, there is a higher degree of wellconsidered reference practices. This can be explained in so far that, in special-field dictionary articles with a fixed reference position, the article form already takes into account a genuine feature of special-field knowledge which consists of being systematic coherent knowledge, and therefore a
\end{abstract}

* Translation of a German contribution to the Festschrift for Regina Hessky (see Brdar-Szabó and Knipf-Komlósi 2004). For this translation, it was slightly altered. I thank Maria Smit for the translation.

Lexikos 14 (AFRILEX-reeks/series 14: 2004): 195-221 
fixed reference position is provided, that means: not only defining and additional explanation is important in the formation of the article, but also the creation of connections which go beyond articles by means of references. Making references, therefore, is not a lexicographical action performed more or less concomitantly; rather, it obtains a relevant place because of being explicitly taken into account in the microstructural programme, and thus in the article form.

Keywords: SPECIAL-FIELD DICTIONARY ARTICLE GIVING A CROSS-REFERENCE; MEDIOSTRUCTURE; FIXED REFERENCE POSITION; VARIABLE REFERENCE POSITION; MEDIOSTRUCTURAL SELECTION; ITEM-BOUND REFERENCE; POSITION-BOUND REFERENCE

Abstract: Überlegungen zur Mediostruktur in Fachwörterbüchern. Auch am Beispiel des Wörterbuchs zur Lexikographie und Wörterbuchforschung. Die zentrale Fragestellung des Beitrages lautet: Worin besteht der Unterschied zwischen einem verweisvermittelnden Fachwörterbuchartikel mit festgelegter textueller Verweisposition einerseits und einem verweisvermittelnden Fachwörterbuchartikel ohne festgelegte Verweisposition andererseits im Hinblick auf eine systematische Verweisvermittlung? Da die sehr spezielle Fragestellung nur relativ zu einer Theorie der Mediostruktur systematisch bearbeitet werden kann, werden zunächst anhand exemplarischer Analysen von verweisvermittelnden Fachwörterbuchartikeln einige notwendige Termini eingeführt, wie z.B. homogen außenorientierter Wörterbuchartikel, heterogen außenorientierter Wörterbuchartikel, Verweisausgangsangabe, Verweisangabe, Angabe mit Verweiskennzeichnung, mediostrukturelles Artikelnetz, verweisrelevantes Benutzervorwissen, positionsgebundene Verweisung, angabegebundene Verweisung, einfacher und erweiterter Verweisausgangsbereich, mediostrukturelle Selektion und zahlreiche weitere. Anhand mehrerer Analysen unterschiedlicher Fachwörterbuchartikel mit variabler und fester Verweisposition ergibt sich ein Bild, das es nahelegt, dass die Ausgangsfrage des Beitrages wie folgt beantwortet werden kann: Sowohl wenn die Ergebnisse einer angemessenen mediostrukturellen Selektion durch eine Anwendung der Methode der angabegebundenen Verweisung in Fachwörterbuchartikeln mit variabler Verweisposition präsentiert werden, als auch wenn dies durch eine Anwendung der Methode der positionsgebundenen Verweisung in Fachwörterbuchartikeln mit fester Verweisposition geschieht, kann im Prinzip eine systematische, an den Wörterbuchfunktionen orientierte Verweisung erfolgen. Durchgehend ist jedoch festzustellen, dass in Fachwörterbuchartikeln mit festgelegter Verweisposition eine in höherem Grad reflektierte Verweisungspraxis angetroffen wird. Dies lässt sich so erklären, dass in Fachwörterbuchartikeln mit fester Verweisposition bereits in der Artikelform eine genuine Eigenschaft fachlichen Wissens, die darin besteht, systematisch zusammenhängendes Wissen zu sein, ausdrücklich dadurch berücksichtigt wird, dass eine feste Verweisposition angelegt ist, d.h.: Nicht nur Definieren und weiterführendes Erklären ist bei der Artikelgestaltung wichtig, sondern auch das Herstellen von artikelübergreifenden Zusammenhängen durch Verweisen. Verweisen ist damit kein lexikographisches Handeln, das mehr oder weniger nebenbei erfolgt; vielmehr erhält es dadurch einen relevanten Stellenwert, dass es im Mikrostrukturenprogramm und damit in der Artikelform ausdrücklich berücksichtigt wird.

Stichwörter: VERWEISVERMITTELNDER FACHWÖRTERBUCHARTIKEL, MEDIOSTRUKTUR, FESTE VERWEISPOSITION, VARIABLE VERWEISPOSITION, MEDIOSTRUKTURELLE SELEKTION, ANGABEGEBUNDENE VERWEISUNG, POSITIONSGEBUNDENE VERWEISUNG 


\section{What it is about and what it is not about}

Systematic analyses of the mediostructure of special-field dictionaries are rare in metalexicography. They will also not be given here. This contribution does not deal with an exhaustive presentation of the provision of reference data and furthermore not with a detailed description of the mediostructural programme of the Dictionary for Lexicography and Dictionary Research (DLDR); it also does not deal with a presentation of the abstract mediostructure of this special-field dictionary and its various partial structures (in the sense of Wiegand 2002: 222ff) ${ }^{1}$. On the contrary, the theme of my selected "reflections on the mediostructure in special-field dictionaries" results from the following question: Is there really a systematic difference between a special-field dictionary article giving a crossreference with a fixed textual reference position on the one hand, and a specialfield dictionary article giving a cross-reference without a fixed textual reference position on the other hand, from the perspective of giving cross-references in a systematic way? And if yes, what does it exist of? Even though these questions result from my experience with special-field lexicography, they are nevertheless very specific; they cannot be answered convincingly in an ad hoc manner by reaching for practical experiences, but only in relation to refined theoretical pre-set guidelines; these are put forward in my newer works on the theory of lexicographical text carriers, which consists of two partial theories, namely, a theory of dictionary structure and a theory of dictionary subject (cf. Wiegand 1998: 8ff). In what follows, I draw particularly on the following works in which above all central aspects of the first-mentioned partial theory are expressed: Wiegand 2000, 2001, 2001[2002], 2002, 2002a, 2002b, 2002c, 2003, 2003a. The notions introduced in these works cannot again be developed systematically here. Rather, the terms in the next section which are necessary for the argument by means of which the question can be answered, i.e. by contemplating some special-field dictionary articles which do not stem from the DLDR, are applied and only occasionally provided with exemplary explanations. ${ }^{2}$

\section{Special-field dictionary article giving cross-references: illustrative analy- ses for introducing terminology}

Given here are two special-field dictionary articles giving secondary crossreferences; dictionary article $1\left(\mathrm{da}_{1}\right)$ exhibits variable reference positions and a fixed reference position at the end of the article; accordingly da $a_{1}$ belongs to the articles with variable and final reference position(s); $\mathrm{da}_{2}$, on the other hand, exhibits only variable reference positions (cf. Figure 2-1).

$\mathrm{da}_{1}$ :

Essigsäure: Acidum aceticum glaciale, Azetsäure, Äthansäure, $\mathrm{CH}_{3} \mathrm{COOH}$. Wasserklare, stechend riechende, leicht brennbare, mit Luft explosive Gemische bildende Flüssigkeit, die unterhalb $16^{\circ} \mathrm{C}$ zu einer kristallinen Masse erstarrt (个 Eisessig). E. kommt in zahlreichen Naturprodukten, z.B. $\mathrm{da}_{2}$ :

grauer Markt

$\rightarrow$ Markt, auf dem durch die Festsetzung eines $\rightarrow$ Mindestpreises, der über dem Gleichgewichtspreis $(\rightarrow$ Preisbildung, $\rightarrow$ 
äther, Ölen, in freier und gebundener Form vor. Salze und Ester werden als $\uparrow$ Azetate bezeichnet. Die E. hat in Form des $\uparrow$ Azetylkoenzym A im intermediärstoffwechsel große biochem. Bedeutung. Sie wird von zahlreichen Bakterien beim Abbau der Kohlenhydrate in den Vormägen und Dickdarmabschnitten der Pflanzerfresser gebildet, beim Rind in Mengen bis zu etwa $4000 \mathrm{~g}$ pro Tag. Wird von den meisten Geweben der Pflanzenfresser verbrannt. Dient in der laktierenden Milchdrüse bes. zur Synthese der kurz- und mittelkettigen Fettsäuren. Bei der Fettbildung erscheinen mittekettion Fettüunse wirkt stark ätzend auf Haut und Schleimhaut, resorptiv nephrotoxisch und hämolytisch. Etwa $20 \mathrm{ml}$ wirken oral für den Menschen tödlich.
Gleichgewicht) liegt, ein Angebotsüberschuß entsteht. Dieser induziert Geschäfte unterhalb des Mindestpreises, so daß ein bestimmtes Produkt zum offiziellen Mindestpreis, aber auch auf dem g. zu einem niedrigeren Preis gehandelt wird. Ein sinnentsprechendes Beispiel ist der Verkauf eines $\rightarrow$ Markenartikels auch als namenloses Produkt zu einem geringeren Preis.

Figure 2-1: da from Wiesner and Ribbeck (1991) and da 2 from Woll (1992)

Special-field dictionary articles belong to the dictionary articles giving secondary cross-references when they exhibit at least one text segment giving a cross-reference. In the partially condensed article $\mathrm{da}_{1}$, the following text segments giving cross-references are exhibited:

— $\quad$ the habitual complete item giving a reference " $\uparrow$ Eisessig"

- two habitual, morphosyntactically integrated reference markers, namely

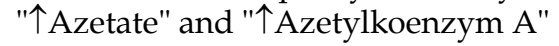

- the homosegmental reduced item giving a reference "6, 13"

The latter numerical item giving a reference, orientated towards the outer text, stands in a fixed textual final reference position, which appears in all dictionary articles in Wiesner and Ribbeck (1991) as textual article positions. In the also partially condensed article $\mathrm{da}_{2}$, the following text segments giving cross-references can be found:

- three habitual, morphosyntactically integrated reference markers, namely, " $\rightarrow$ Markt", " $\rightarrow$ Mindestpreises" and " $\rightarrow$ Markenartikels" (cf. under 3.)

- two habitual reference markers in parentheses, namely, " $\rightarrow$ Preisbildung" and " $\rightarrow$ Gleichgewicht", with which the reference address is designated verbatim.

Special-field dictionary articles, which do not exhibit text segments giving cross-references, are not dictionary articles giving cross-references.

Both $\mathrm{da}_{1}$ and $\mathrm{da}_{2}$ are polydirectional dictionary articles: different external cross-reference addresses are designated in both. Whereas, however, only lemmatic external cross-reference addresses are designated in $\mathrm{da}_{2}$, which consequently all lie in the same structure, namely, the macrostructural access structure, the numerical outer text external cross-reference addresses "6" and "13" are both designated in $\mathrm{da}_{1}$ in addition to lemmatic external cross-reference addresses, and both lie within an external numerical outer text access structure belonging to the mediostructural access structures (in the sense of Wiegand 2003). The mediostructural orientation of both multiple externally orientated 
special-field dictionary articles is therefore different: $\mathrm{da}_{2}$ belongs to the homogeneously externally orientated dictionary articles, and $\mathrm{da}_{1}$, in contrast, belongs to the heterogeneously externally orientated ones (cf. Wiegand 2003).

The special-field article giving a cross-reference $\mathrm{da}_{3}$ (in Figure 2-2) is - as opposed to $\mathrm{da}_{1}$ and $\mathrm{da}_{2}$ - simply externally orientated, and in fact outer text orientated.

da3:

Essig: Verdünnte Essigsäurelösungen für Gewürz- und Konservierungszwecke. Der meiste E. wird durch Gärungsverfahren gewonnen. Nach den Rohstoffen bzw. der Gärentahro gew rungsmaische unterscheidet man Spritessig, echten Weinessig, Weinessig $20 \%$ und $40 \%$ Malzessig, Obstessig, Bieressig. Gärungsessig enthält noch Aromastoffe, die als Stoffwechselprodukte der Essigbildner aufgefaßt werden können. Die übl. Handelssorten enthalten 5 bis $10 \mathrm{~g} \mathrm{E.-Säure} \mathrm{je} 100 \mathrm{ml}$. E.-Essenz enthält $50 \mathrm{~g} \mathrm{E}$.Säure in $100 \mathrm{~g}$ und wird durch Verdünnen von Syntheseessigsäure (Eisessig) hergestellt. Eine 80\% sur in Flaschen besimer Form und besonders deklarf nur in Flaschen bestimmter Form und besonders deklariert
gehandelt werden.

Figure 2-2: Dictionary article da 3 from Wiesner and Ribbeck (1991)

Because $\mathrm{da}_{1}$ and $\mathrm{da}_{3}$ are from the same special-field dictionary, the question arises why these special-field dictionary articles are not mediostructurally linked. This question concerning dictionary criticism, results from the fact that, whereas the reference prerequisites determined by the scope of the dictionary subject (in the sense of Wiegand 2002a: 172) are such that a text segment giving a cross-reference in the form of " $\uparrow$ Essigsäure" in $\mathrm{da}_{2}$ can be expected, there are nevertheless dictionary-specific reasons why this expectation would be unjustified. These reasons which would be justifiable from a lexicographical-theoretical point of view, can only be explained with reference to the system of dictionary functions (in the sense of Wiegand 2001[2002]: 228ff) assigned to the dictionary. However, nothing is stated in the front matter texts of Wiesner and Ribbeck (1991) on this matter, and in fact also not in the informal language used in the lexicographical practice. In the accompanying metatext (the guidelines for the use of the dictionary), one finds the following guidelines on the mediostructure for the practice of referring under "3. Other" [!].

\section{(Z 2-1: Wiesner and Ribbeck 1991)}

3.1 The marker $\uparrow$ stands as guideline with the meaning that the special-field word is being described by the following keyword, e.g.

Augenfliege $\uparrow$ Musca autumnalis

or in the text with the meaning that the word following is explained as keyword, e.g. ... differentialdiagnostisch muß auch $\uparrow$ Tollwut beachtet werden.

3.2 At the end of a definition one or more numbers are presented, which refer to the author or authors (see list of authors).

In 3.1 in Z 2-1, text segments of pure reference articles are "explained" in the first instance, namely by means of the example of "Augenfliege $\uparrow$ Musca au- 
tumnalis" and therefore by means of an incomplete reference article, because the last (right-aligned) text segment "14", which forms the fixed final reference position, is lacking. Although the "explanation" is intelligible, it is nevertheless obviously nonsensical in one respect. Then, of course, the "special-field word" Augenfliege is not described in the reference article, i.e. in the special-field dictionary article on Musca autumnalis, but specific features (of veterinary medical relevance) are described of a pastural fly which is called Augenfliege by farmers and of which the scientific name of the species is Musca autumnalis. The reference prerequisite stipulated by the dictionary subject is consequently the system-transcendental synonym relation of Augenfliege and Musca autumnalis. The same semantic relation is also the reference prerequisite stipulated by the dictionary subject in the following pure reference articles (cf. Figure 2-3).

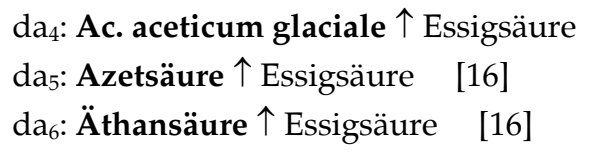

Figure 2-3: Pure reference articles da ${ }_{4} \mathrm{da}_{6}$ from Wiesner and Ribbeck (1991)

The numbers "14" and " 16 " in the three reference articles da $_{4}-\mathrm{da}_{6}$ as well as the numbers "6" and "13" in $\mathrm{da}_{1}$ and $\mathrm{da}_{3}$ deal with items of the numerical index of author names, which are at the same time outer text orientated items giving a reduced reference; they are outer text-orientated because, by means of them, a numerical outer text external cross-reference address is designated, which lies in the numerical external mediostructural outer text access structure $<1 .<2 .<3$. $<\ldots<72$. < 73. > (with "<" standing for "precedes"). Each numerical outer text external cross-reference address opens, in the process of performing the external access actions, access to an outer text rubric of the outer text "list of authors". For example, "14" opens the external access to the following outer text rubric (= otr 1 ), which consequently functions as outer-textual reference goal rubric:

otr $_{1}$ : 14. Prof. Dr. sc. med. vet. Regine Ribbeck, Leipzig (Arachno-Entomologie, Pharmakologie, Allgemeines)

The external access to otr 1 is, of course, only possible in the process of performing a procedure of following up a reference. A user who accesses from outside, can therefore only read in the list of authors; $\operatorname{otr}_{1}$ is consequently an indirectly accessible outer text entry (in the sense of Wiegand 2003).

All reference articles in Wiesner and Ribbeck (1991) are heterogeneously externally orientated, because with them at least two external cross-reference addresses are designated at any given time, which lie in different outer access structures.

The three reference articles $\mathrm{da}_{4}-\mathrm{da}_{6}$ form the reference article periphery of a mediostructural article network internal to the word list, of which the centre of reference lies within $\mathrm{da}_{1}$, so that the article network is centred towards $\mathrm{da}_{1}$. 
Wiesner and Ribbeck (1991) contains hundreds of $\mathrm{da}_{\mathrm{n}}$-centred article networks of the same article network type. All these article networks exhibit a concrete partial mediostructure which belongs to the same structural type. In order to give formally correct representations of the partially concrete mediostructures which belong to the article network in Wiesner and Ribbeck (1991), some classes of items giving cross-references and classes of reference addresses necessary for this purpose are introduced in such a way that their names (which function as class symbols) are listed and supplied with an explanation with regard to the contents, as follows:

- VerwAuA $A_{W / R}$, the class of all items identifying the starting-point of the reference in Wiesner and Ribbeck (1991)

- VerwAuA.VAW/R, the class of all items identifying the starting-point of the reference in reference articles in Wiesner and Ribbeck (1991)

- Verw $A_{W / R}$, the class of all items giving a reference in Wiesner and Ribbeck (1991)

- VerwA.VA ${ }_{W / R}$, the class of all items giving a reference in reference articles in Wiesner and Ribbeck (1991)

- VerwAuAd.l $l_{\mathrm{W} / \mathrm{R}}$, the class of all lemmatic (l) external cross-reference addresses in Wiesner and Ribbeck (1991)

- VerwA.red.n $\mathrm{W}_{\mathrm{W} / \mathrm{R}}$, the class of all numerical (n) reduced (red.) items giving a reference in Wiesner and Ribbeck (1991)

- UmtAuAd.nW/R, the class of all numerical (n) outer text external crossreference addresses in Wiesner and Ribbeck (1991)

The concrete da 1 -centred article network structure with reference article periphery can now be represented in Figure 2-4.

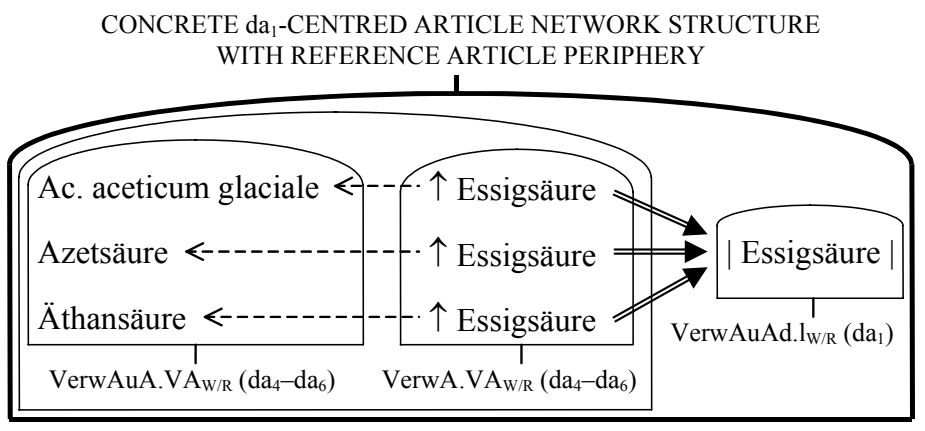

Figure 2-4: Structural representation of a concrete partial mediostructure from Wiesner and Ribbeck (1991) with the name da $a_{1}$-centred article network structure with reference article periphery. Notational conventions: " $\mathrm{x}--\rightarrow \mathrm{y}$ " means $x$ is article internally addressed to $y$; " $\mathrm{x} \Longrightarrow \mathrm{z}$ " means $x$ is mediostructurally addressed to $z$. 
Apart from the word list-internal article networks, of which the centre of reference lie within a dictionary article, mediostructural article networks appear in Wiesner and Ribbeck (1991), of which the centre of reference forms an outer text rubric with numerical reference address. All dictionary articles of which the outer text orientated numerically reduced items giving a reference are equidirectional (so that by means of them the same numerical outer text external cross-reference addresses are designated in the fixed reference positions), belong to a mediostructural article network which exceeds the word list. In this way, for example, all dictionary articles, and in fact the reference articles as well as all other articles which exhibit a reduced item giving the reference "14" and therefore stem from one author, belong to such an article network.

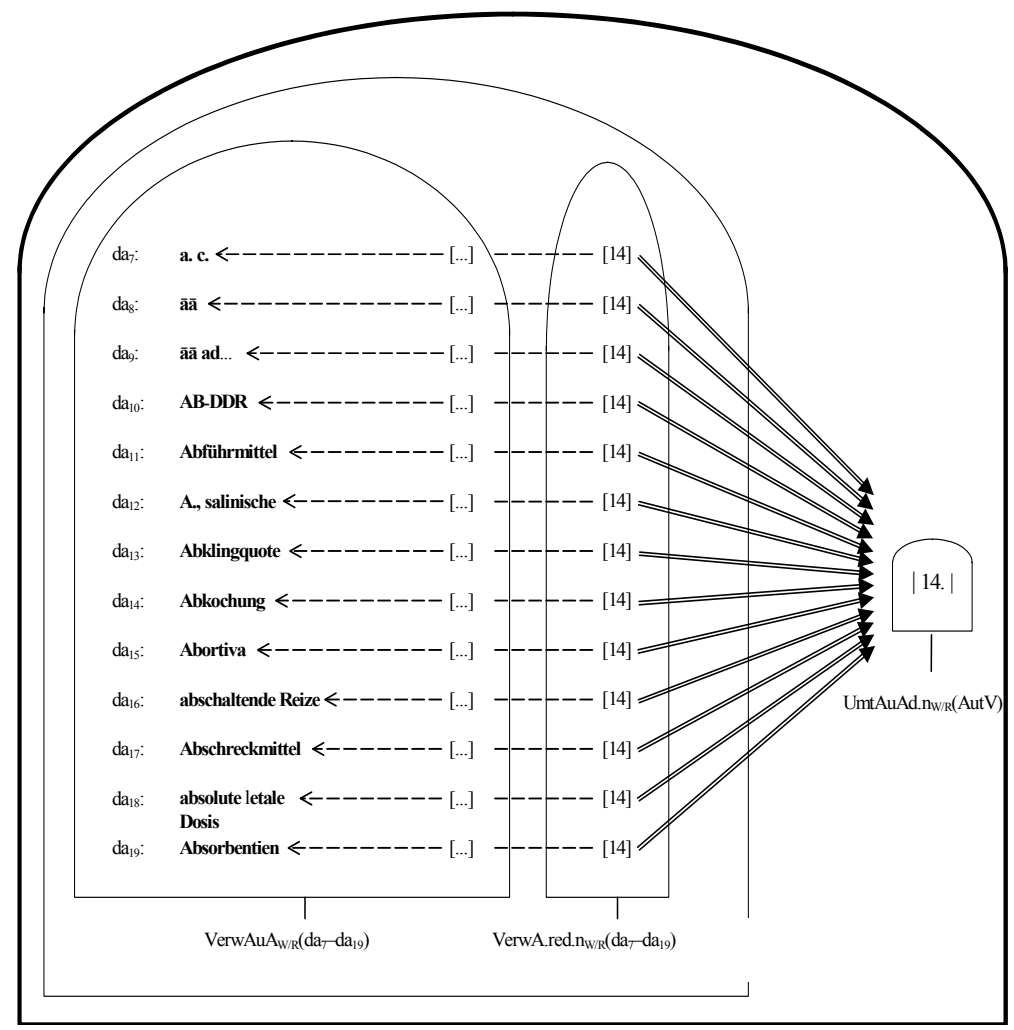

Figure 2-5: Structural representation of an excerpt from a concrete partial mediostructure from Wiesner and Ribbeck (1991) with the name otr 1 -centred article network structure with article periphery. Notational conventions: " $\mathrm{x}--[\ldots]--\rightarrow \mathrm{y}$ " means $x$ is article-internally non-adjacently addressed to $\mathrm{y} ; \mathrm{x} \Longrightarrow \mathrm{z}$ means $x$ is mediostructurally addressed to $z$. Abbreviation: $A u t V=$ list of authors 
Figure 2-5 shows a small excerpt from the concrete partial mediostructure which belongs to the outer text rubric-centred article network exceeding the word list, of which the reference centre is the above-mentioned outer text rubric $\operatorname{otr}_{1}$ with the numerical reference address "14". The excerpt only takes into account the non-functional article stretch, which ranges from the dictionary article with the lemma $\mathbf{A}$ to the article with the lemma Abzeichen; in this article stretch are thirteen articles $\left(\mathrm{da}_{7}-\mathrm{da}_{19}\right)$ which exhibit a reduced item giving the reference "14".

The reference articles, which belong to the article periphery of an outer text-centred article network in Wiesner and Ribbeck (1991), are always also part of the reference article periphery of a dan-centred article network.

After this exemplary insight into the functioning of special-field dictionary articles giving cross-references as well as into some of their text segments giving cross-references within the framework of mediostructural article networks, we also need some more precise knowledge about the differences between article-internal items giving references on the one hand, and article-internal items with reference markers on the other hand (cf. for the following Wiegand 2002a: $216 \mathrm{ff}$ ). We first look at some features and the functioning of items giving references; the terminological refining is withheld on an intermediate level.

Items giving a reference such as, for example, "个Eisessig" in $\mathrm{da}_{1}$ and "^Essigsäure" in $\mathrm{da}_{4}-\mathrm{da}_{6}$, are monofunctional items giving cross-references of which the genuine purpose exclusively exists in the fact that a reference is made accessible. Items giving references are article constituents which stand in a particular textual reference position, in which, under certain circumstances, additional items giving references could appear (cf., for example, Figure 3-5). In the structural analysis of condensed or partially condensed dictionary articles, each textual reference position is in accordance with a microstructural reference position as excerpt from the concrete sequential order of the microstructure. Each item giving a reference, whether it is complete or reduced, is addressed twice. Firstly, it exhibits an article-internal relation address, which forms the item identifying the starting-point for the reference. Secondly, it is always mediostructurally addressed to a reference address; this reference address is designated with the item giving the reference address as a partial item of the item giving the reference (therefore in the reference position). In da5, for example, the item giving the form of the lemma sign "Azetsäure" is the item identifying the starting-point for the reference and "Essigsäure" is the item giving the reference address; with the latter the guiding element |Essigsäure $\mid$ of the lemma Essigsäure in $\mathrm{da}_{1}$ is designated, so that it is possible for a user-in-action who has accessed the reference, to perform, knowing this guiding element, an external procedure of following up a reference, which would lead him/her to the designated address. That he/she should (or can) do this, can be inferred in the case of complete items giving the reference, such as, for example, "^Essigsäure", by means of the habitual items giving the reference relation " $\uparrow "$ ". In da5, the item giving the reference is adjacently addressed to the left, so that the address distance is zero and so that, by means of the item giving the reference, 
together with the item identifying the starting-point for the reference, a single domain for the starting-point for the reference is identified. Accordingly, one talks of a reference position with a single domain for the starting-point for the reference. No pre-knowledge relevant to references is needed for a single domain for the starting-point for a reference. How one should understand this remark, is illustrated by means of a simple example (= E 2-1). A user-in-action - he/she is called $B_{1}$ - who has consulted and read, for example, the pure reference article $\mathrm{da}_{5}$ with the search question of the type WHAT IS AZETSÄURE?, cannot infer, by means of the item identifying the starting-point for the reference "Azetsäure", any knowledge which can be considered relevant for the solution whether or not to accept the references supplied by means of the item giving the reference "^Essigsäure". Rather, if he/she wants to reach his/her original user's aim, $B_{1}$ takes this and opens up an obligatory reference leading straight to the article, getting lexicographical information of the contents and learning that he/she must perform an external procedure of following up a reference to reach the external cross-reference address |Essigsäure | which in turn opens up external access to the entire reference goal article with the lemma Essigsäure (that is to $\mathrm{da}_{1}$ ), so that $\mathrm{B}_{1}$ has the possibility to solve the search question by means of appropriate search question-specific selected lexicographical data in $\mathrm{da}_{1}$, which then function as data for the reference goal. The knowledge gap which led to the use of the dictionary directly becomes the knowledge situation relevant to the reference for the user-in-action more or less simultaneously with the successful external access to the lemma Azetsäure, namely then, when the user-in-action establishes that he/she is being referred to another article. If one assumes that $B_{1}$ infers by means of the item giving the synonym "Azetsäure" in da ${ }_{1}$ firstly that acetic acid (Azetsäure) is the same as Essigsäure (in German) and then by means of the following item giving the definiens which follows the formula " $\mathrm{CH}_{3} \mathrm{COOH}$ " finds a solution to his/her search question, then the item giving the synonym and the item giving the definiens function as items giving the reference goal within the reference goal article. With this, it should be sufficiently clear what it means when one speaks about the fact that no pre-knowledge relevant to the reference is needed for a domain for the starting-point for a reference.

Next we look at an additional example (= E 2-2), which links up with (E 21 ). We assume that the interest of the user is aroused, on the basis of reading the item giving the definiens in $\mathrm{da}_{1}$, for the fact that acetic acid solidifies below $16^{\circ} \mathrm{C}$ into a crystalline substance. For this reason, $\mathrm{B}_{1}$ opens up, by means of the habitual item giving the reference "^Eisessig", which directly follows the item giving the definiens in $\mathrm{da}_{1}$, a reference going straight to the article, which has the result that he/she then performs a consultation procedure motivated by the reference (in the sense of Wiegand 1988: 412). The item giving the reference " $\uparrow$ Eisessig" is non-adjacently addressed to the left to the item giving the form of the lemma sign "Essigsäure" which functions as item identifying the startingpoint for the reference. Between the item giving the reference and its non-adjacent reference address situated to the left, the following five elementary items 
occur: the three items giving the synonyms "Acidum aceticum glaciale", "Azetsäure", and "Äthansäure"; the item giving the formula " $\mathrm{CH}_{3} \mathrm{COOH}$ " and the item giving the definiens "Wasserklare [...] erstarrt". The distance in addressing which exists between the addressed item and its relation address, is calculated (in the sense of Wiegand 2002b: 144ff) according to the number of elementary items which stand between the item giving the reference " $\uparrow$ Eisessig" and "Essigsäure" (cf. also da 29 ); it consequently adds up to five, so that a five-fold expanded addressing relation exists between "^Eisessig" and "Essigsäure". An expanded domain for the starting-point for the reference thus belongs to the reference position in which "^Eisessig" stands; this is in accordance with the domain of expansion of the addressing relation multiplied by the item identifying the starting-point for the reference. In clear contradistinction to a reference position with a single domain for the starting-point for the reference, a reference position with an expanded domain for the starting-point for the reference needs user pre-knowledge relevant to the reference. This is all the more extensive, as more propositional contents are opened up by means of the expanded domain for the starting-point for the reference. The user's pre-knowledge relevant to the reference is therefore precisely that propositional knowledge a user-in-action can have by cognitively working successfully through the items and/or item texts in the expanded domain for the starting-point for the reference, and which functions when determining whether a reference provided should be accepted or not. The user's pre-knowledge relevant to the reference should be looked at again.

Next we look at the second type of item giving a cross-reference, the item giving a marker for the reference. Reference markers are functional supplements to the item, therefore it is not possible to isolate them by means of the method of functional-positional segmentation. Items with reference markers are items giving cross-references which are always at least bi-functional. Their primary genuine function is determined by the class of items with the same general genuine purpose to which they belong. The function of cross-referring is never their primary function, but always a subordinate one (mostly secondary). For example, the first item in $\mathrm{da}_{2}$ belongs to the items with reference markers; it is a bi-functional item giving the cross-reference and the definiens, namely, one with four reference markers. Its primary function lies in the fact that it has to present the definiens as part of the definition; its secondary function is the function of referring. Numerous classes of items with the same general genuine purpose have a subclass with corresponding items giving crossreferences, for example:

- an item giving the paraphrase of the meaning/an item giving the crossreference and the paraphrase of the meaning

- an item giving a competence example/an item giving a cross-reference and a competence example

- an item giving a phrase/an item giving a cross-reference and a phrase. 
In $\mathrm{da}_{20}$, "bei $\nearrow$ Licht $\mathrm{b} . "$ is a condensed item giving a cross-reference and a phrase.

$\mathrm{da}_{20}$ :

besehen (er besieht), besah, hat besehen jmdn., etw. genau ansehen (1.3): ich besah ihn (mir) aufmerksam, näher, von oben bis unten; sich den Schaden b.

+ bei $\nearrow$ Licht $b$.

Figure 2-6: Dictionary article da 20 from HWDG (1984)

In $\mathrm{da}_{20}$, the item giving the cross-reference and the phrase is addressed to the item giving the form of the lemma sign "besehen". This does not function, however - as in the case of items giving the reference - as an item identifying the starting-point for the reference. In da $_{20}$, the lexicographer does not refer the user-in-action from "besehen" to the external cross-reference address $\mid$ Licht $\mid$; rather, the user-in-action is referred from "bei $\rtimes$ Licht b." to $\mid$ Licht $\mid$ and therefore to the article on Licht. This means: the item identifying the starting-point for the reference is at the same time the condensed item giving the cross-reference and the phrase. The same is true of the item giving the cross-reference and the definiens in $\mathrm{da}_{2}$. In principle, the following is true: each item with a reference marker functions at the same time as an item identifying the starting-point for the reference. An additional substantial difference with items giving a reference lies in the fact that the items with reference markers do not stand in their own textual reference positions. For example, "bei $\nearrow$ Licht b." in $\mathrm{da}_{20}$ stands in the postcomment to the phraseology, which is clearly no reference position. Accordingly, the domain giving the starting-point for the reference in items with reference markers is linked to the particular item and not to the fixed article position; therefore one speaks of an item-bound (short: bound) domain giving the starting-point for the reference and of an item-bound reference. On the basis of the expandability of the addressing relation, items giving a reference are variable with regard to their position; that means one can fix reference positions in the microstructure programme totally independently from the textual positions of other items. Items giving a reference can therefore be inserted in a more versatile way than items with reference markers, where this flexibility is not possible. For example, in the same dictionary, an item giving the cross-reference and the paraphrase of the meaning can stand in the same textual position as an item giving the paraphrase of the meaning. Accordingly, also in $\mathrm{da}_{21}$, the condensed item giving the phrase "vor jmdm., etw. auf der $\mathrm{H}$. sein" stands in the same textual position as the item giving the cross-reference and the phrase in $\mathrm{da}_{20}$.

$\mathrm{da}_{21}$ :

${ }^{2}$ Hut, die; -, /o. Pl.; in den Verbindungen/ geh. in guter H. (Obhut) sein; jmdn., sich in guter H. wissen 
+ vor jmdm., etw. auf der H. sein (sich vor jmdm., etw. in acht nehmen)

Figure 2-7: Dictionary article da 21 from HWDG (1984)

After the illustrative analyses of special-field dictionary articles giving crossreferences undertaken so far in 2., in which not all mediostructurally relevant aspects were taken into account at all, we have at our disposal the necessary theoretical tools to try to answer the question posed in 1. about the systematic difference between special-field dictionary articles giving cross-references with a fixed textual reference position and those without a fixed reference position with regard to the systematic provision of references - now also taking into account the DLDR.

\section{Special-field dictionary articles with versus special-field dictionary articles without reference position}

Special-field dictionary articles without a fixed reference position, and consequently those with one or more variable reference positions, are, for example, all the articles giving cross-references in Glück (2000) which are no pure reference articles; an example is $\mathrm{da}_{22}$ in Figure 3-1.

$\mathrm{da}_{22}$ :

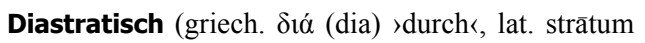
>Decke`, d.h. >sich über verschiedene Schichten erstreckend $\iota$ ) Auf verschiedene Sozialschichten gleichzeitig bezogene (ling.) Untersuchungsmethodik oder Sichtweise; Ggs. synstratisch. D. Forschungsfragen fallen per definitionem in den Aufgabenbereich der $\nearrow$ Soziolinguistik. Dazu gehören z.B. Untersuchungen der restringierten und $\nearrow$ elaborierten $\nearrow$ Kodes, der Verwendung von $\nearrow$ Dialekten und Standardvarietäten, von $\nearrow$ Bildungssprache, von $\nearrow$ Sprachbarrieren und Möglichkeiten $\nearrow$ kompensatorischer Erziehung; $\nearrow$ diachronisch, $\nearrow$ diaphasisch, $\nearrow$ diatopisch.

$\mathrm{AM}$

Figure 3-1: Dictionary article $\mathrm{da}_{22}$ from Glück (2000)

As opposed to Wiesner and Ribbeck (1991), the item giving the abbreviation of the author names "AM" at the end of $\mathrm{da}_{22}$ is not an item giving a cross-refence, because it is not introduced in the accompanying metatext as a means of referring. Therefore "AM" also does not stand in a fixed reference position as, for example, "13" in da3. The consultation act of a user-in-action who wants to know who hides behind the "AM" and therefore consults, in the front matter of Glück (2000), the list of authors, should for that reason not be understood - as 
demonstrated in Wiegand (2002a: 198ff) in an argument with Kammerer and Lehr (1996) - as follows: A user infers, by means of "AM", an outer text-orientated reference, subsequently performing a procedure of following up a reference. "AM" therefore is not a potential item constituting a reference (in the sense of Kammerer and Lehr 1996). Rather, the user performs a habitual consultation procedure with a consultative search question (for example, questions such as: Who compiled the article? or: What does "AM" mean?). The motive for the user action is therefore not to open up a reference, but rather, by using a dictionary, to solve a (relatively harmless) text reception disturbance, for which elimination had been provided by the compilation of the list of authors.

In $\mathrm{da}_{22}$, a partially condensed dictionary article, the item giving the antonym "synstratisch", is followed by an item text. This contains ten morphosyntactical integrated, habitual reference markers, from " $\nearrow$ Soziolinguistik" to $" \nearrow$ diatopisch". It should besides be mentioned that with morphosyntactical integrated, externally orientated reference markers, the external cross-reference addresses are often not designated literally, but instead with inflectional forms of those lemma signs which belong to the reference goal article. This is also the case in $\mathrm{da}_{22}$, namely in the five cases combined in the following overview (cf. Figure 3-2).

\begin{tabular}{|c|c|c|c|}
\hline \multicolumn{2}{|c|}{ Reference markers } & \multirow{2}{*}{$\begin{array}{l}\text { Lemma-internal } \\
\text { leading element as } \\
\text { external cross- } \\
\text { reference address }\end{array}$} & \multirow{2}{*}{$\begin{array}{l}\text { Lemma of the } \\
\text { reference goal article }\end{array}$} \\
\hline $\begin{array}{c}\text { Reference relation } \\
\text { markers }\end{array}$ & $\begin{array}{c}\text { Reference address } \\
\text { markers }\end{array}$ & & \\
\hline$\pi$ & elaborierten & | elaboriert $\mid$ & Elaboriert \\
\hline$\pi$ & Kodes & $\mid$ Kode $\mid$ & Kode \\
\hline$\pi$ & Dialekten & | Dialekt $\mid$ & Dialekt \\
\hline$\pi$ & Standardvarietäten & |Standardvarietät $\mid$ & Standardvarietät \\
\hline$\pi$ & Sprachbarrieren & |Sprachbarriere $\mid$ & Sprachbarriere \\
\hline
\end{tabular}

Figure 3-2: Morphosyntactical integrated reference markers, which designate inflectional forms

German users who master the practice of general dictionary use (in the sense of Wiegand 1998: 370), can probably infer the external cross-reference address from the designated inflectional forms without problems; for non-native speakers, it could already be different. The accumulation of morphosyntactical integrated reference markers in item texts, to which reference markers in parentheses are also added in many dictionary articles in Glück (2000), can by no means be considered user-friendly (cf. also Tarp 1999: 128). The practice of referring certainly appears to be really problematic when one questions its significance. If one asks about the "significance" of a part of the lexicographical practice (to which the accompanying practical results also belong, cf. Wiegand 
1998: 34ff), then one asks about their specific usefulness and the textual organisation of the user relation. This, however, always also means: one asks about the types of situations of dictionary use to which those situations of use also belong where a dictionary should be usable with success, and consequently also about the types of users (e.g. laypersons, semi-experts, experts) who belong to the circle of addressees. In other words, this means that one poses the following question: Which dictionary functions (in the sense of Wiegand 2001[2002]) are supported by which results of lexicographical description practice?

In Glück (2000), there are only some very general and rather insignificant explanations for user reference in the (reprinted) preface to the first edition, which creates the impression that they came out of the economic pen of a publishing-house reader and not out of the head of a scientist who knows what he/she writes and who has to be committed to the truth. There is no explanation about which user groups of the circle of addressees were particularly favoured and how the dictionary functions attached to the linguistic special-field dictionary are structured hierarchically. If one assigns the dictionary function of text reception (short: the reception function) as primary function to Glück (2000), as it were as an experiment, then the presented section in $\mathrm{da}_{22}$ from the mediostructural selection (as the selection from the set of all possible references) can be considered completely meaningless. Because a user who comes across a usage of diastratisch unknown to him/her in a linguistic text, in such a way that he/she does not understand the text section, and, for example, consults the linguistic special-field dictionary with the search question of the type WHAT DOES THE TERM X MEAN?, does not need anything more than an understandable, but nevertheless correct (according to the special-field) item giving the definiens or an item text giving the definition by means of which the meaning of the term can be inferred. If additional terms are found in the defining text parts, the mediostructural selection has to be organised in such a way that references are made to these terms. This does not already state how this should best be done, namely, whether in a fixed reference position or by means of items or item texts with reference markers or by means of a combination of both methods of referring. Corresponding text segments giving crossreferences are then article constitituents or parts of them, which strengthen the reception function of the dictionary and supports the user in those instances of dictionary use which belong to the situation type covered by the dictionary function supporting the text reception (cf. Wiegand 2001[2002]: 238ff). In addition, if one assigns, as an experiment, the function of conveying specific specialfield information to Glück (2000), which belongs to the non-conflict related dictionary functions, then, for example, the following argument could result: Let us assume that a student (who can be categorised as a semi-expert) works on a major assignment about the notion of "diasystem", and in the process of data collection consults $\mathrm{da}_{22}$. For him/her, it can be absolutely useful to accept the references supplied in $\mathrm{da}_{22}$. In order to strengthen the specific special-field information in a special-field dictionary, it certainly is not necessary to write 
item texts decorated with reference arrows such as the one in $\mathrm{da}_{22}$. It namely suffices if there is a single sentence in a prominent place in the user's guidelines; this could, for example, be: "All linguistic terms used in dictionary articles are included as lemmata and are explained in the accompanying dictionary article." Such a sentence, which can also be understood as an expression of applying the method of omission of references, only explicitly emphasises what could be considered as the most important principle for making references in special-field lexicography for specific types of special-field dictionaries, to which particularly dictionaries for one specific field or part of a field, aimed at semi-experts, belong.

It is unnecessary and not useful to document the so-called permanent adherence to this principle with thousands of unnecessary reference arrows which obstruct reading. This practice in special-field lexicography, as one finds it, for example, in Glück (2000), also does not improve when it can be found in different variants in numerous special-field dictionaries. It looks like a contagious special-field lexicographical textual illness which is healed by means of a mostly arrow-formed virus from the family of mediostructural print viruses (which are related to certain electronic linking viruses), a virus which attaches itself to all items designating special-field terms when these special-field terms are also designated by means of a lemma.

Of course, the item-bound reference, i.e. the method of reference which leads to items with reference markers functioning as items identifying the starting-point for a reference, or which leads to item texts giving cross-references, can also be applied in a meaningful way. Whether such a reference without a fixed reference position can be considered meaningful or not, depends above all on three factors: (a) on the special-field scope of the dictionary subject, (b) on the type of dictionary, and (c) on the functions of the dictionary.

If one considers, for example, Wiesner and Ribbeck (1991) with regard to (a)-(c), the following argument arises: in Z 2-1 we read, for example, that the reference arrow " $\uparrow "$ in the dictionary text signifies that the word which follows it, has been explained as a keyword; with that, nothing wrong has been said, but also nothing very important, while it remains open in which cases the reference arrow had been used. The accompanying practice of reference is as follows: in the articles, the upward arrow is used only very occasionally; in addition, terms which have their own dictionary article, are relatively often used without there being a reference to these articles. That is, for example, the case in $\mathrm{da}_{23}$ in Figure 3-3.

$\mathrm{da}_{23}$ :

Chalazion, n. 〈griech.〉 (Hagelkorn): Etwa erbsengroße, chronisch granulierende Entzündung mit Riesenzellausbildung einzelner Meibom' Talgdrüsen am Tarsus palpebrae, häuftig durch Hyperkeratose und Sekretstauung ausgelöst. In fortgeschrittenen Fällen bleibt eine Verunstaltung der Lider nicht aus, die dann zum chirurg. Eingriff zwingt.

$[26,71]$

Figure 3-3: Dictionary article da ${ }_{23}$ from Wiesner and Ribbeck (1991) 
For the following terms in $\mathrm{da}_{23}$, there are independent dictionary articles to which this article does not refer: Entzündung, Meibom' Drüsen, Tarsus, Palpebra and Hyperkeratose. In addition, there is an article for Riesenzelle. One could have organised the mediostructural selection in such a way that an article such as the following in Figure 3-4 could have resulted.

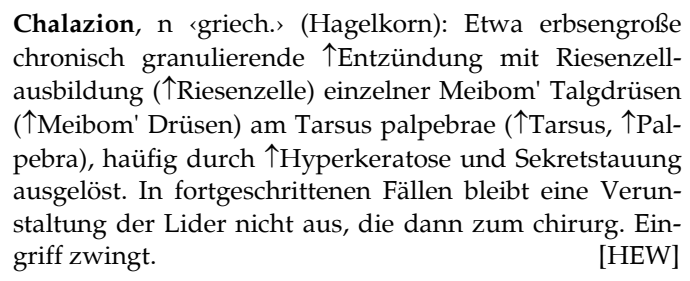

[HEW]

Figure 3-4: Dictionary article da' 23

The fact that this method was not used as in $\mathrm{da}_{23}$ (and thus not as in $\mathrm{da}_{22}$ ), clearly shows that it was presupposed that the potential users of Wiesner and Ribbeck (1991) would be experts with academic knowledge, namely, above all veterinary surgeons and perhaps advanced semi-experts (for example, advanced students in veterinary medicine). This interpretation is also supported by the observation that in many dictionary articles various terms are often used in the items giving the definiens and in the encyclopedic item texts which are not included as a lemma in Wiesner and Ribbeck (1991). This is, for example, the case in $\mathrm{da}_{24}$ in Figure 3-5.

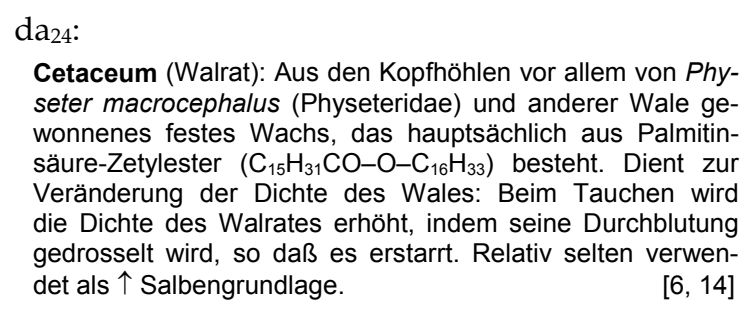

Figure 3-5: Dictionary article da 24 from Wiesner and Ribbeck (1991)

Physeter macrocephalus and Palmitinsäure-Zetylester are not included as lemmata. In order to appropriately interpret this element of lexicographical practice, one also has to consider the following, in my view (cf. (a)): The scope of the dictionary subject in Wiesner and Ribbeck (1991) is explicitly heterogeneous. In the selection of lemmata, the following fields of study, for example, were taken into account: history of veterinary medicine, animal protection, animal insurance, cytology, histology, endocrinology, disinfection, feeding principles, footand-mouth disease, internal veterinary medicine, veterinary hygiene, poultry diseases and about 80 additional fields. Not all of the terms stemming from 
these fields and used in the articles can also be included and explained primarily, because that would cause an obligation to explain them once again in turn; rather, one should presuppose a knowledge of them or at least the knowledge where to find them in a reference work. According to the positioning of Wiesner and Ribbeck (1991) so far, it is consequently a comprehensive special-field dictionary specifically for experts. If one presupposes now that the primary dictionary functions are the function of reception and the function of conveying special-field information, then the following positive evaluation of the referring practice can be made: References are only made to articles when there is a good chance that a user-in-action with a genuine veterinary medical search question which emerges during text reception in a situation of study can broaden his/her veterinary medical knowledge by means of the data in these articles, if he/she accepts the references provided.

Even though therefore the application of the method of bound reference, which leads to items and item texts with reference markers, can result in a meaningful reference practice if the mediostructural selection of the parameters (a)-(c) are taken into account, is it nevertheless striking that in special-field dictionaries in which the method of position-bound reference resulted in fixed reference positions, one can mostly find a higher measure of well-considered reference practices. The articles $\mathrm{da}_{25}-\mathrm{da}_{28}$ exhibit, for example, a fixed reference position.

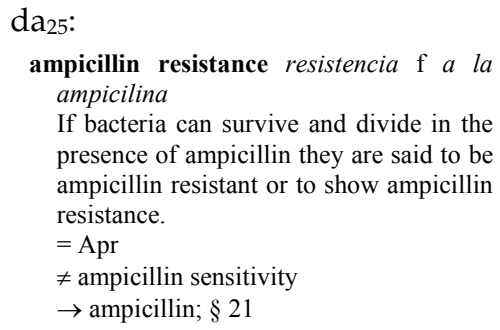
que interfiere con las divisiones celulares. La colchicina se une a los microtúbulos e impide la formación de fibras del huso funcionales. Como resultado, los cromosomas no se separan y permanecen en metafase. Mediante el tratamiento con colchicina, de los extremos de las raíces $\mathrm{u}$ otras partes de las plantas en crecimiento, es posible, en algunos casos, producir plantas en las que se ha duplicado el número de cromosomas.

- Quizás la primera prueba directa de una alteración específica de la membrana plasmática, en la resistencia a múltiples

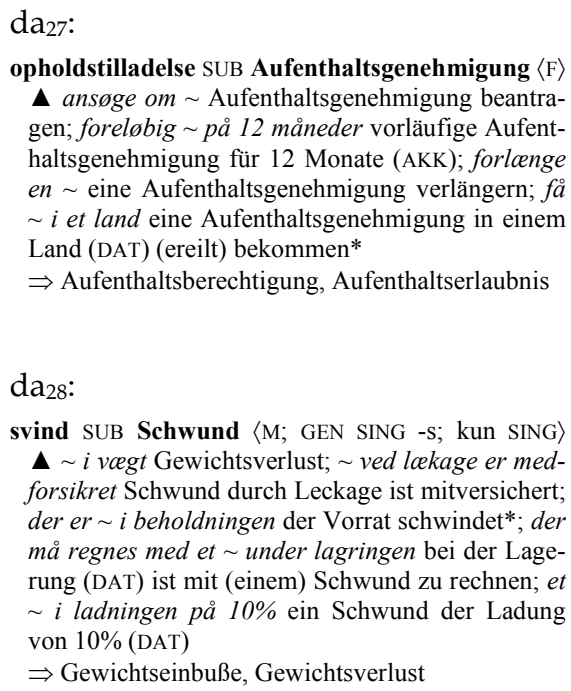
haltsgenehmigung für 12 Monate (AKK); forlcenge en $\sim$ eine Aufenthaltsgenehmigung verlängern; $f a ̈$ $\sim i$ et land eine Aufenthaltsgenehmigung in einem Land (DAT) (ereilt) bekommen*

$\mathrm{da}_{28}$ :

svind SUB Schwund $\langle\mathrm{M}$; GEN SING -s; kun SING

$\Delta \sim i$ veegt Gewichtsverlust; ved laekage er medforsikret Schwund durch Leckage ist mitversichert; der er $\sim i$ beholdningen der Vorrat schwindet*; der må regnes med et $\sim$ under lagringen bei der Lagerung (DAT) ist mit (einem) Schwund zu rechnen; $e t$ $\sim i$ ladningen på $10 \%$ ein Schwund der Ladung von $10 \%$ (DAT)

$\Rightarrow$ Gewichtseinbuße, Gewichtsverlust 
medicamentos, la obtuvimos con nuestros estudios sobre las células de hamster chino, que eran resistentes al medicamento colchicina.

$\rightarrow$ cromosoma; meiosis; mitosis; aparato del huso.

Figure 3-6: Dictionary articles $\mathrm{da}_{25}$ to $\mathrm{da}_{28}$ from Kaufmann and Bergenholtz (1998) and from Lauridsen et al. (1999)

In all four special-field dictionaries in Figure 3-6, the textual reference position stands at the end of the article, so that dictionary articles with final reference position are given. The right arrow is at times the habitual item giving the reference relation, which at the same time functions as the item giving the identification for the reference position. In $\mathrm{da}_{25}$, the heterogeneously outer-orientated habitual item giving the reference " $\rightarrow$ ampicillin; §21" stands in the reference position, which designates with its first item giving the external crossreference address "ampicillin", a lemmatic external cross-reference address, and with its second item giving the reference address "\$21", an alpha-numerical outer text external address of which the place to find the reference address is the outer access structure of the systematic introduction "Introduction to Molecular Biology" in the front matter of Kaufmann and Bergenholtz (1998). In the reference position of $\mathrm{da}_{26}-\mathrm{da}_{28}$, there are at times homogeneously outerorientated, habitual items giving a reference, because all designated reference addresses belong to the lemmatic external cross-reference addresses and at times lie in the same macrostructural access structure. All four articles in Figure 3-6 exhibit an expanded domain for the starting-point for the reference. With regard to the organisation of the reference position, articles such as those in Figure 3-6 were examples for the special-field dictionary articles in DLDR, on which we are now going to focus.

The DLDR is a polylingualised terminological special-field dictionary; on the level of the outer texts and in the definitorial section of the dictionary articles, it is bilingual (German and English). For the German lemmata, equivalents from ten languages are presented. ${ }^{3}$

The primary dictionary functions which are assigned to the DLDR are the reception function and the function of conveying special-field information. The secondary dictionary functions are the translation supporting dictionary function (short: translation function) and the production supporting dictionary function (short: text production function). The circle of addressees consists of semi-experts and experts. In what follows, only the primary functions are taken into account. The fixed reference position is located at the place in the dictionary article where lexicographical statements about the meaning of the term Adressenentfernung and those about special-field features of "distancing of address" are already dealt with, so that the definition position, the position for additional explanations and the position for an excerpt from the terminological network including the item giving the form of the lemma sign "Adressenentfernung" which functions as item identifying the starting-point for the ref- 
erence, form the expanded domain for the starting-point for the reference. That knowledge which a user-in-action can acquire about the term Adressenentfernung and about distancing(s) of address, forms the user's pre-knowledge relevant to the reference. In what follows, the explanation is continued by means of an example.

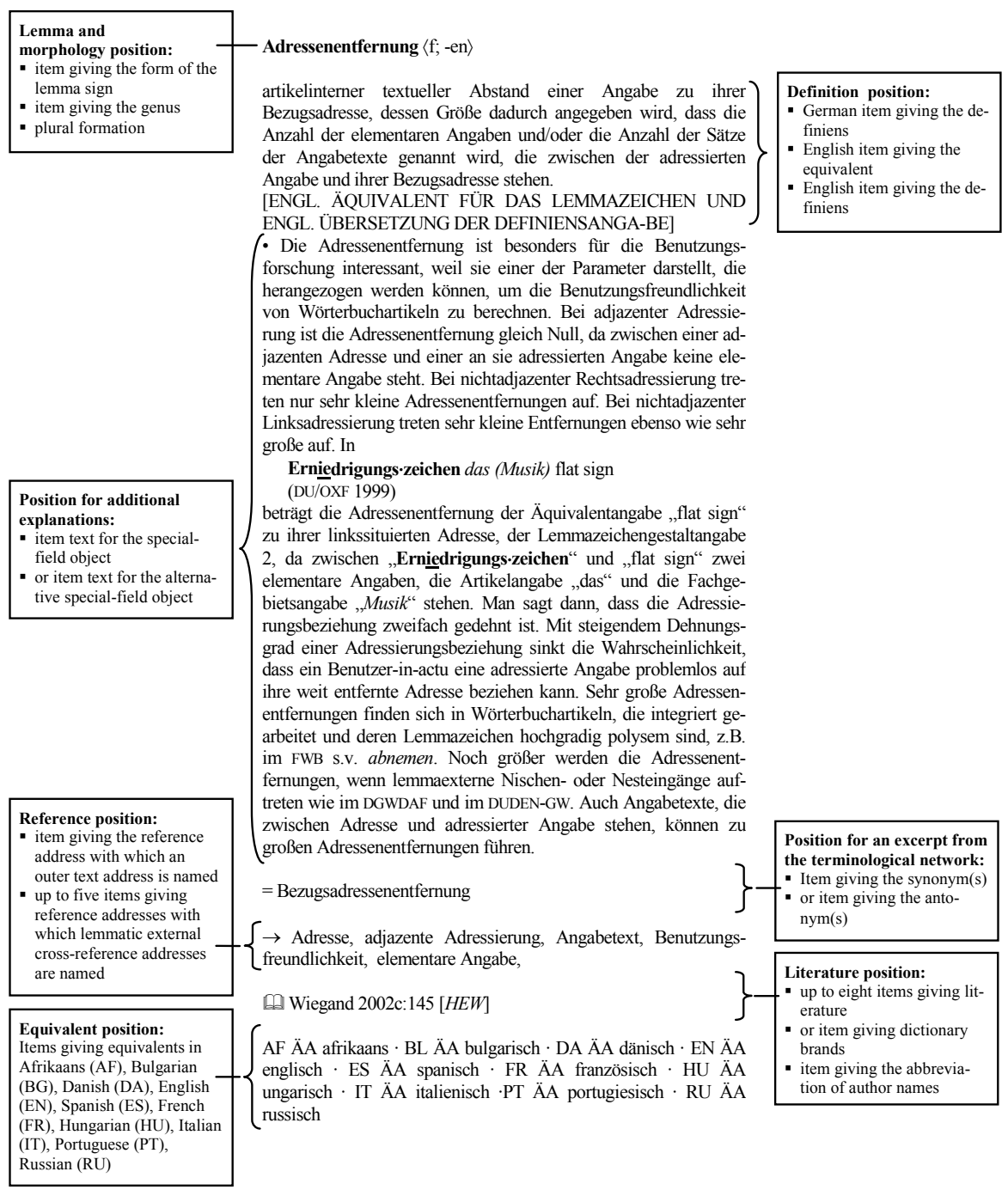

Figure 3-7: Illustration of da 29 , a (middle-sized) DLDR-article, which deals with a reduced single article, since the article positions for the item text for the alternative special-field object and the antonym position are empty. 
E 3-1: Our user-in-action, $\mathrm{B}_{1}$, while reading a special-field text, comes across the term Adressenentfernung, which is unknown to him/her, so that it cannot be guaranteed that he/she will understand the metalexicographical special-field text. Therefore a text reception disturbance exists. If $\mathrm{B}_{1}$ should turn to the DLDR, he/she would be in a conflict-conditioned consultation situation, which belongs to the type of situations of dictionary use covered by the text reception supporting function assigned to the DLDR. Accordingly, when $\mathrm{B}_{1}$ has reached $\mathrm{da}_{29}$ after having made an external access procedure with the search question of the type WHAT DOES ONE UNDERSTAND UNDER ADRESSENENTFERNUNG?, he/she has to be supported by the article text in such a way that the solution to the search question can be found. Depending on the way in which the knowledge situation particularly takes shape for the user-in-action, the required answer can already be found after reading the German item giving the definiens, which should be valid in E 3-1. In this case, one part of the user's pre-knowledge relevant to the reference, which belongs to the expanded domain for the starting-point for the reference, closes the knowledge gap for the user-in-action. Here, in the last instance, the question arises about the motive for designation and the coining of the term user's pre-knowledge relevant to the reference, because in example E 3-1, $\mathrm{B}_{1}$ does not actually infer a reference by means of the item in the fixed reference position. In the rest of the argument, one should therefore take into account that this question of a terminological nature should be answered. With regard to both primary functions, namely, the reception supporting dictionary function and the function of conveying specific special-field related information, specifically that knowledge is relevant to the reference (from the viewpoint of a lexicographer of a terminological dictionary such as the type the DLDR represents) which tunes in with the userin-action when reading the item giving the definiens. Because, understanding the item giving the definiens is, in the first place, the presupposition of the fact that all consultative search questions should be answered according to the meaning of the term, and in addition, also for the fact that, in the second place, the special-field explanations are being understood. The knowledge of the definition which comes into being when reading the item giving the definiens, is special-field encyclopedic object-constituting meaning knowledge and determines that the definiendum is something specific in the special field and not something unspecific or something else (cf. Wiegand 1988: 772ff). A specialfield lexicographer of a terminological dictionary of the type of the DLDR should therefore set up the textual assumptions in such a way that the knowledge of the definition can be obtained by the user-in-action. Because of the fact that, in a worthwhile special-field dictionary for experts and semi-experts, terms related in a lexicographically-external manner to the term which forms the particular lemma sign, are also used in the items giving the definiens, there arises an obligation for reference related to the knowledge of the definition with regard to both dictionary functions, in case a user-in-action does not know a term which appears in the item giving the definiens. This obligation for reference which exists particularly for the sake of semi-experts, can be fulfilled by 
the lexicographer in various different ways, in that he/she could apply either one of the following methods of reference mentioned, or a combination of methods. The already mentioned methods of lexicographical reference are: the item-bound reference, the position-bound reference, and the omission of a reference.

In the application of the method of item-bound reference, the item giving the definiens in $\mathrm{da}_{29}$, for example, would have been given as an item giving the cross-reference and the definiens. It could then, for example, have both the following forms:

(a) article-internal textual distance of an $\lambda$ item to its $\lambda$ relation address, of which the value is given in such a manner that the number of $\lambda$ elementary items and/or the number of sentences of $\lambda$ item texts which stand between the $\lambda$ addressed item and its relation address, are named.

(b) article-internal textual distance of an item to its relation address, of which the value is given in such a manner that the number of elementary items and/or the number of sentences of the items texts which stand between the addressed item and its relation address, are named.

(a) is an item giving the definiens with habitual, non-demarcated reference markers; the reference markers are integrated morphosyntactically.

(b) is an item giving the definiens with typographical reference markers; here also, the reference markers are integrated morphosyntactically.

The method of position-bound reference is applied in $\mathrm{da}_{29}$. In the reference position, reference is made to, amongst others, the articles to the address of the terms designated in the item giving the definiens (as superordinate of Bezugsaddresse - "relation address"), the item text and the elementary item.

In the application of the method of omission of reference, the following sentence would, for example, be found in the accompanying metatext: "All terms used in the position of the definition appear as headword and are explained in that particular article." In this case, the omission of reference is restricted to the position, and the user has to be informed separately in the metatext what the reference practice in the rest of the articles will look like. Item-bound reference and position-bound reference can be combined. Hartmann and James (1998) worked with this combination of methods. The application of the method of omission of reference does not, of course, automatically have the result that every term becomes a potential item constituting a reference (in the sense of Kammerer and Lehr 1996). Rather, with this method, it should be taken into account that each term used in items and item texts can potentially create conflict in the sense that it could cause a disturbance in the text reception during the process of dictionary use.

The user's pre-knowledge relevant to the reference, which belongs to the expanded domain for the starting-point for the reference, is not only relevant from the viewpoint of the lexicographer, but also from the perspective of the 
user-in-action. Whoever has understood the entire explanatory dictionary text after reading $\mathrm{da}_{29}$, is faced with an offering of references in the closing section of the article. The user can ignore them or (partially) accept them: the appropriate decision is, however, determined (if not exclusively) by the user's preknowledge relevant to the reference. Particularly in the context of non-communicative usage (in the sense of Wiegand 1998: 531), items giving a reference can be used by means of which expletive or additional references can be opened up. Such items giving references strengthen the specific subject-related information function of the dictionary. In $\mathrm{da}_{29}$, it is particularly the item giving the lemmatic external cross-reference address "Benutzerfreundlichkeit" that provides for the opening up of additional references.

In order to take into account another aspect, a section of a second article from DLDR is presented.

\section{Angabe der semantischen Lemmatisierung}

$$
\langle\mathrm{f} ;-\mathrm{n}\rangle
$$

Angabe, anhand derer erkannt werden kann, wie der semantische Teil der Lemmatisierungsaufgabe gelöst wurde.

[ENGL. ÄQUIVALENTANGABE, ENGL. DEFINIENSANGABE]

- Die Angabe der semantischen Lemmatisierung ist entweder als Polysemieangabe oder als Homonymieangabe realisiert. Hierbei können die semiotischen Details der Realisierung verschieden sein. - Symbol für die Angabeklasse: A.semL

$\rightarrow$ § 14, Angabe, Homonymieangabe, Polysemieangabe, semantische Lemmatisierung

[d] Reichmann 1989: 72f; Wiegand 1991:

398, 419, 2003; Zöfgen 1998 [HEW]

[ÄQUIVALENTPOSITION]

Figure 3-8: $\mathrm{da}_{30}$ from DLDR

In the reference position of $\mathrm{da}_{30}$, five items giving the reference address follow the habitual item giving the reference relation " $\rightarrow$ ". With the first, namely, "§14", an alphanumerical outer text reference external address is designated which lies in the external access structure of the integrated outer text "Systematic Introduction" and which directly opens up access to §14 "Die Bauteile von Wörterbuchartikeln" ("The components of dictionary articles"). This reference particularly strengthens the specific subject-related information function of the dictionary. Whoever accepts the offering of references as a semi-expert, has a good chance to get a quick overview of the other components of the dictionary. Because an outer text reference position is given at the end of $\$ 14$, from which reference is made to articles, and in fact especially to synoptic articles (e.g. the 
articles on Angabe, Mikrostrukturanzeiger, lexikographische Bearbeitungseinheit), the user can purposefully continue the action of reference on the basis of questions which come up. The article-heterogeneous list of words of the DLDR is consequently mediostructurally linked to the Systematic Introduction by means of the method of bi-directional reference. In this way, for example, all synoptic and single articles in which reference position the item giving the outer text external address $\$ 14$ appears, form the article periphery of an article network, of which the centre is $\$ 14$.

In the reference position of da $\mathrm{a}_{30}$, four alphabetically ordered items of lemmatic outer addresses follow on "\$14". These were conceptualised as follows: reference is made to the synoptic articles in which the superordinate to the lemma sign "Angabe der semantischen Lemmatisierung", namely, Angabe, has been treated lexicographically. Because Angabe der semantischen Lemmatisierung is itself a generic term, reference is made to both the hyponym terms Homonymieangabe and Polysemieangabe. In order to support the compilation of the definition knowledge, reference is finally made to the article with the lemma semantische Lemmatisierung. With the four items of lemmatic outer addresses, a small coherent part of the network is consequently "cut" out of the terminological-semantic network to which the terms belong.

Here we break off the illustrative explanations and try to answer the question at the beginning in the summary in the next section.

\section{Summary}

Subject-field knowledge such as, for example, that from lexicography and dictionary research, does not consist of isolated elements of knowledge. Rather, it is something which is in many ways connected with regard to its contents. Whoever compiles an alphabetical printed dictionary is forced to distribute the data to be presented along the provided text compound constituents. The close connection with regard to the contents can at the same time only be taken into account in a very restricted way. In order to uncover the connection, which is necessarily concealed by the data distribution along the different access positions, a mediostructural network of the lexicographically distributed data has to ensue. The networking is inadequate if everything which belongs together extra-lexicographically is also linked together by means of mediostructural addressing. Rather, a mediostructural selection should result which depends decisively on the primary dictionary functions and consequently on the intended user relation. The question which was formulated in section 1. deals with whether the results of the mediostructural selection (in as far as dictionary articles are concerned when presented by means of the application of the method of bound reference so that special-field dictionary articles without a fixed reference position occur) are present in such a way that these special-field dictionary articles can be distinguished from those (with regard to a systematic 
way of giving cross-references) in which the results of the mediostructural selection are presented according to the method of position-bound reference.

Firstly, it has to be established that both types of special-field dictionary articles giving cross-references allow for appropriate articles with systematically conceptualised reference. Apart from the many smaller differences which we have already come across and which should not be repeated here, a substantial systematic difference exists, in my view, in the fact that in articles giving cross-references with a fixed reference position, a genuine feature of the subject-knowledge, namely, coherent knowledge carried over by means of a theory, should be explicitly showed and brought to the fore in such a way that it can be seen clearly in the article structure as part of the dictionary structure! Not only the definiens position, the position for additional explanation, and additional positions are provided according to the microstructural programme, but also a reference position. This is an obligation to a theory-driven approach and the systematic method of conveying coherent subject-field knowledge. The fixed reference position enforces, to a great extent, a systematically conceptualised reference, which can at the same time be considered a successful immunisation against the "arrow virus".

\section{Concordance}

\begin{tabular}{|l|l|l|}
\hline $\begin{array}{c}\text { external cross-reference } \\
\text { address }\end{array}$ & Verweisaussenadresse & (VerwAuAd) \\
\hline item giving the reference & Verweisangabe & (VerwA) \\
\hline $\begin{array}{c}\text { item identifying the starting- } \\
\text { point of the reference }\end{array}$ & Verweisausgangsangabe & (VerwAuA) \\
\hline mediostructure & Mediostruktur & (UmtAuAd) \\
\hline $\begin{array}{l}\text { outer text external cross- } \\
\text { reference address }\end{array}$ & Umtextaussenadresse & (VA) \\
\hline reference article & Verweisartikel & \\
\hline $\begin{array}{l}\text { special-field dictionary arti- } \\
\text { cle giving a cross-reference }\end{array}$ & $\begin{array}{l}\text { verweisvermittelnder Fachwör- } \\
\text { terbuchartikel }\end{array}$ & \\
\hline reference marker & Verweiskennzeichnung & \\
\hline
\end{tabular}

\section{Endnotes}

1. For the DLDR cf.: <www.fabulex.de>; furthermore: Kammerer (2001[2002]); Wiegand (2002, 2003a); also compare footnote 3.

2. I shall also only occasionally refer to the mentioned works, and not in the case of every term.

3. The equivalents are researched by the following collaborators: Afrikaans: Rufus H. Gouws (Stellenbosch); Bulgarian: Pavel Petkov (Sofia); Danish: Jens-Erik Mogensen (Copenhagen); English: Rufus H. Gouws; French: Franz Joseph Hausmann (Erlangen); Italian: Giovanni 
Rovere (Heidelberg); Portuguese: Stefan Schierholz (Göttingen); Russian: Dimitri Dobrovol'skij (Moscow); Spanish: Reinhold Werner (Augsburg); Hungarian: Regina Hessky (Budapest). - The editors of the DLDR are: Michael Beißwenger (Dortmund), Rufus H. Gouws (Stellenbosch), Matthias Kammerer (Karlsruhe), Angelika Storrer (Dortmund), Herbert Ernst Wiegand (Heidelberg), and Werner Wolski (Paderborn). - The article structures of the special-field dictionary articles are described in Kammerer 2001[2002]: 263ff, and in more detail in Wiegand (2003a); a general characterisation can be found in Wiegand (2002) with an overview of the entire text compound and a view into the systematic introduction. - The DLDR will be printed in two volumes of about 6000 lemmata including the reference lemmata; it is being written on the internet. At the moment, about 1400 articles are on the internet (protected by password), although without English translation of the item giving the definiens and without the equivalents. These parts will later be added automatically. - The editorial staff of the DLDR who had been in Heidelberg until June 2004, has since July 2004 been located in Dortmund.

\section{Bibliography}

Brdar-Szabé, Rita and Elisabeth Knipf-Komlósi (Eds.). 2004. Lexikalische Semantik, Phraseologie und Lexikographie: Abgründe und Brücken. Festgabe für Regina Hessky. Duisburger Arbeiten zur Sprach- und Kulturwissenschaft 57. Frankfurt am Main/Bern/New York/Paris: Peter Lang.

Glück, Helmut (Ed.). 2000. Metzler Lexikon Sprache 2. Revised and expanded edition with 70 illustrations, 17 of which maps. Stuttgart: Verlag J.B. Metzler.

Hartmann, R.R.K. and Gregory James. 1998. Dictionary of Lexicography. London/New York: Routledge.

HWDG = Kempcke, Günter et al. (Eds.). 1984. Handwörterbuch der deutschen Gegenwartssprache. In two volumes A-K and L-Z. Berlin: Akademie-Verlag.

Kammerer, Matthias. 2001[2002]. XML-getaggte Wörterbuchartikel. Ein Bericht aus der Praxis des Wörterbuchs zur Lexikographie und Wörterbuchforschung. Lexicographica 17: 249-301.

Kammerer, Matthias and Andrea Lehr. 1996. Potentielle Verweise und die Wahrscheinlichkeit ihrer Konstituierung. Wiegand, Herbert Ernst (Ed.). 1996. Wörterbücher in der Diskussion II. Vorträge aus dem Heidelberger Lexikographischen Kolloquium: 311-354. Lexicographica. Series Maior 76. Tübingen: Niemeyer.

Kaufmann, Uwe and Henning Bergenholtz. 1998. Encyclopedic Dictionary of Gene Technology/Diccionario Encyclopédico Ingeniaría Genética. Vol. I: English (With Spanish Equivalents); Vol. II: Español (Con equivalentes en inglés). Toronto: Lugus Libros LatinAmerica Inc.

Lauridsen, Ole, Sven-Olaf Poulsen, Tore Gadegård and Sven Tarp. 1999. Dansk-tysk erhvervsordbog. Viborg: Forlaget Systime.

Tarp, Sven. 1999. Theoretical Foundations of the So-called Cross-reference Structures. Lexicographica 15: $114-137$.

Wiegand, Herbert Ernst. 1988. Was eigentlich ist Fachlexikographie? Mit Hinweisen zum Verhältnis von sprachlichen und enzyklopädischen Wissen. Munske, Horst Haider, Peter von Polenz, Oskar Reichmann and Reiner Hildebrandt (Eds.). 1988. Deutscher Wortschatz. Lexikologische Studien. Ludwig Erich Schmitt zum 80. Geburtstag von seinen Marburger Schülern: 729-790. New York: Walter de Gruyter. 
Wiegand, Herbert Ernst. 1998. Wörterbuchforschung. Untersuchungen zur Wörterbuchbenutzung, zur Theorie, Geschichte, Kritik und Automatisierung der Lexikographie. 1. Teilband. With 159 illustrations in the text. Berlin/New York: Walter de Gruyter.

Wiegand, Herbert Ernst. 2000. Wissen, Wissensrepräsentation und Printwörterbücher. Heid, Ulrich, Stefan Evert, Egbert Lehmann and Christian Rohrer (Eds.). 2000. Proceedings of the Ninth EURALEX International Congress. EURALEX 2000. Stuttgart, Germany, August 8-12, 2000: 1538. Stuttgart: Institut für Maschinelle Sprachverarbeitung, Universität Stuttgart.

Wiegand, Herbert Ernst. 2001. Sprachkontaktwörterbücher. Typen, Funktionen, Strukturen. Igla, Birgit, Pavel Petkov and Herbert Ernst Wiegand (Eds.). 2001. Theoretische und praktische Probleme der Lexikographie. 1. Internationales Kolloquium zur Wörterbuchforschung am Institut Germanicum der St. Kliment Ohridski-Universität, Sofia, 7. bis 8. Juli 2000: 115- 224. Germanistische Linguistik 161-162. Hildesheim/Zurich/New York: Georg Olms.

Wiegand, Herbert Ernst. 2001[2002]. Was eigentlich sind Wörterbuchfunktionen? Kritische Anmerkungen zur neueren und neuesten Wörterbuchforschung. Lexicographica 17: 217-248.

Wiegand, Herbert Ernst. 2002. Zur Makrostruktur und zu den äußeren Zugriffsstrukturen im de Gruyter Wörterbuch Deutsch als Fremdsprache. Wiegand, Herbert Ernst (Ed.). 2002. Perspektiven der pädagogischen Lexikographie des Deutschen II. Untersuchungen anhand des de Gruyter Wörterbuch Deutsch als Fremdsprache: 413-442. Lexicographica. Series Maior 110. Tübingen: Max Niemeyer Verlag.

Wiegand, Herbert Ernst. 2002a. Altes und Neues zur Mediostruktur in Printwörterbüchern. Lexicographica 18: 168-252.

Wiegand, Herbert Ernst. 2002b. Adressierung in zweisprachigen Printwörterbüchern. Wiegand, Herbert Ernst (Ed.). 2002. Studien zur zweisprachigen Lexikographie mit Deutsch VIII: 111-175. Germanistische Linguistik 166. Hildesheim/Zurich/New York: Georg Olms Verlag.

Wiegand, Herbert Ernst. 2002c. Über textuelle Strukturen der Wörterbuchartikel und Artikelnischen im de Gruyter Wörterbuch Deutsch als Fremdsprache. Zugleich ein Beitrag zur Weiterentwicklung einer Theorie der Wörterbuchform. Wiegand, Herbert Ernst (Ed.). 2002. Perspektiven der pädagogischen Lexikographie des Deutschen II. Untersuchungen anhand des de Gruyter Wörterbuch Deutsch als Fremdsprache: 497-595. Lexicographica. Series Maior 110. Tübingen: Max Niemeyer Verlag.

Wiegand, Herbert Ernst. 2003. Überlegungen zur Typologie von Wörterbuchartikeln in Printwörterbüchern. Ein Beitrag zur Theorie der Wörterbuchform. Lexicographica 19 [2004]: 169-313.

Wiegand, Herbert Ernst. 2003a. Wörterbuch zur Lexikographie und Wörterbuchforschung/Dictionary of Lexicography and Dictionary Research. Städtler, Thomas (Ed.). 2003. Wissenschaftliche Lexikographie im deutschsprachigen Raum. Im Auftrag der Heidelberger Akademie der Wissenschaften: 417-437. Heidelberg: Winter.

Wiesner, Ekkehard, and Regine Ribbeck (Eds.). 1991. Wörterbuch der Veterinärmedizin. Compiled by 73 scientists. 2 volumes. Third revised edition. Jena/Stuttgart: Gustav Fischer Verlag.

Woll, Artur (Ed.). 1992. Wirtschaftslexikon. Sixth revised and expanded edition. Munich/Vienna: R. Oldenbourg Verlag. 